\title{
The Correlation of Emotional Intelligence and Spiritual of Intelligence to Effectiveness Principals of Leadership
}

\author{
Agung Kurniawan, Abdul Syakur \\ Pharmaceutical Academy of Surabaya, Surabaya, Indonesia \\ Email address: \\ m4615ter@yahoo.co.id (A. Kurniawan),d0kt012@gmail.com (A. Syakur)
}

\section{To cite this article:}

Agung Kurniawan, Abdul Syakur. The Correlation of Emotional Intelligence and Spiritual of Intelligence to Effectiveness Principals of Leadership. International Journal of Psychological and Brain Sciences. Vol. 2, No. 1, 2017, pp. 1-9. doi: 10.11648/j.ijpbs.20170201.11

Received: September 6, 2016; Accepted: January 14, 2017; Published: February 23, 2017

\begin{abstract}
The study focuses on the correlation of emotional Intelligence and spiritual of intelligence to effectiveness principals of leadership. For principals especially lead SMA country in Surabaya can develop and maintain Effectiveness of its leadership among others by exploiting emotional intelligence and spiritual of intelligence by together. The paper found: 1). There is a significant relationship between emotional intelligence on the effectiveness of the leadership of the head of state high school in the city of Surabaya with a correlation coefficient of 0.848 and effective contribution of $85.3 \%$. 2). There is a significant relationship between spiritual intelligence on the effectiveness of the leadership of the head of state high school in the city of Surabaya, the correlation coefficient of 1.014 and effective contribution of $82 \%$. 3). There is a significant relationship between emotional intelligence and spiritual intelligence together on the effectiveness of public SMA leadership chief in the city of Surabaya with correlation coefficients together at 0.963 and effective contribution of $92.7 \%$.
\end{abstract}

Keywords: Emotional Intelligence, Spiritual Intelligence, Principals of Leadership

\section{Introduction}

Entering the era of globalization, the human resource Indonesian people is not competitive. According to the International Education Achievement (IEA) reported that the reading skills of elementary school students Indonesia ranks 38 of 39 countries surveyed. Meanwhile, Third Mathematics and Science Study (TIMSS), which measures the results of educational institutions in the world, reported that the mathematical skills junior high school students in Indonesia ranks 34 out of 38 countries, while the ability of the IPA is in the order of 32 of the 38 countries. Other international organizations also strengthen it. Human Development Report 2003 version of the UNDP report that ranked HDI (Human Development Index), or the quality of Indonesian human resources in the order of 112. Indonesia is much below the Philippines (85), Thailand (74), Malaysia (58), Brunei (31), South Korea (30), and Singapore (28) (Burhanuddin, 2015: 2 ). Thus, according to these data we can conclude that the quality of education in Indonesia is lower when compared with countries in Asia. Therefore, education reform continues to be done especially in terms of curriculum improvement for the quality of education in Indonesia to be better.
The Indonesian government in this case The Ministry of National Education (Kemdiknas) has made great efforts to improve the quality of national education. One of the efforts that have been made Kemdiknas is curriculum improvement. Since 2004 the government has been implementing Competency Based Curriculum (KBK) as complement the 1994 curriculum, which tend to be based on the content. Completion of the curriculum has to be done to respond to the demands of the democratic life, globalization, and regional autonomy. After that the government tried to enhance of KBK to create a new curriculum that education unit level curriculum (KTSP).

In the organization of education, KTSP can be run as expected with the help of various parties, especially the principal. The principal as school leaders have an obligation to develop educational organization, in other words the organization in the field of education with all its personnel do their utmost to improve the quality of education in Indonesia.

Principals can provide the best service to teachers if principals do with good leadership. This can be achieved if the existing leadership in carrying out cooperation to get the full support of the teachers in performing their duties. Good school leadership will make effective leadership in the principal. Therefore, a leader in leading the organization with 
education expected to have all the intelligence in him. Referred to intelligence that not only alone but also intellectual intelligence and emotional intelligence, intelligence spiritual.

On the stage of modern life, Goleman has popularized the term "emotional intelligence". During this time people get to know and trust the "intelligence quotient" rational, logical, and mathematical. Daniel Goleman affirmation of their "emotional intelligence" has built a new awareness, emotional intelligence is not as important as intellect. Emotional intelligence is able to give a sense of empathy, love and motivation. Emotionally intelligent can also respond appropriately sadness or excitement.

Spiritual intelligence (SQ) is the intelligence of the soul, an intelligence that can help heal and build them as a whole. SQ is the intelligence to face and solve the problem of meaning and value, the intelligence to put the behavior and life in the context of a broader meaning and rich, intelligence to judge that the action or the way a person's life is more meaningful than others. SQ is a necessary basis for the proper functioning effectively IQ and EQ. Even SQ is the highest human intelligence. With Spiritual Quotient (SQ) man can build a variety of new perspectives in life. People who have a high SQ will be part of the solution not part of the problem. That is, the SQ could make man as being complete or perfect man intellectually, emotionally and spiritually.

The concept of leadership is usually referred to as the process by which a person influences another individual to obtain a particular purpose. Therefore, to be able to influence other individuals who needed a communication between individuals. This means that a leader must have the social skills, while social efficiency in the opinion of the experts is an element of emotional intelligence. If a leader has a good emotional intelligence and supported with good leadership will support the work ethic.

In this study focuses on the correlation of emotional Intelligence and spiritual of intelligence to effectiveness principals of leadership

\section{Literature Review}

\subsection{Emotional Intelligence}

Emotional Quotient (EQ) is the ability to perceive, understand, and effectively apply the power and sensitivity of emotions as a source of energy, information, connections and influence humane (Cooper and Sawaf, 1998). It is also delivered by Salovey and Mayer (in, Stein and Book, 2002) defines emotional intelligence as the ability to recognize feelings, reach and awaken your senses to help the mind, understand the feeling and meaning, and control their feelings in a manner that fosters emotional and intellectual.

Goleman popularized the theories of intelligence expert opinion that there are other aspects in human beings that interact actively with the intelligence aspects of intellectual intelligence (IQ) in determining the effectiveness of the use of the conventional intelligence. He called it emotional intelligence and linking them with the ability to manage feelings, the ability to perceive situations, act in accordance with that perception, the ability to empathize, and others. If someone is not able to manage aspects of taste owned well, it will not be able to use the conventional aspects of intelligence (IQ) effectively, according to Goleman (Adhipurna, 2001).

From the results of research on the brain and behavior, Goleman attention to why people are high IQ flounder and those whose IQ is being managed and successful. From the results of this study include factors a person who selfawareness and impulse control, persistence, zeal and selfmotivation, empathy and social skills are all that is called emotional intelligence.

Emotional intelligence is not emerging from a clear intellect but of the work of the human heart. The word "emotion" can simply be defined as applying "movement" to remove feelings. Intelligence emotional motivates a person to seek the benefits and potential, and to enable the aspirations and values most in, and turn from what is thought to be what is undertaken. Emotions were long considered to have the depth and strength of the human person. Emotions in Latin called "Motus Anima" which means spirit moves a person. Intelligence requires a person to learn to recognize and appreciate the feelings of self and others as well to be respected respond appropriately, implement effectively energy information and emotions in life and daily work (Cooper and Sawaf, 2002: xv).

According to Homes and Herald (in Agustian, 2002: 3) emotional intelligence is a component that makes a person smarter in using the emotions and feelings (subconscious) to understand about yourself and another people. Meanwhile, according to Cooper and Sawaf (2000) Emotional intelligence is the ability to feel and understand and effectively apply the power and sensitivity of emotions as a source of energy, information, and human influence.

Research about EQ on using instruments Baron EQ-i divide into five scales: intrapersonal Scale: self-esteem, emotional self-awareness, assertiveness, independence, selfactualization; Scale Interpersonal: empathy, social responsibility, interpersonal relationships; Scale adaptability: a reality test, flexibility, problem-solving; Stress management scale: resistance stress, control impulses (impulse); Scale general mood: optimism, happiness (Stein and Book, 2002).

To control emotions, to read other people's feelings and social relationships as well as possible, namely by putting emotion and anger in the proper and appropriate levels, at the right time, for the right purpose and the right way and good (Goleman, 2001: 16).

The ability to get angry very important because if you do not have it, you'll let things that should not be tolerated. According to Homes and Herald (in Agustia, 2002: 30) if you are not angry, you may be cynical, and if you lose your rage level when watching an oppression, then you decrease your level of concern on the oppressed. 
To lead an organization of a school principal is required to control his emotions, because when seen from factors faced by the school principal that is dealing with school personnel, both teachers and employees of non-teacher, then the principal is responsible to the person haris be patient carefully, calm and patient in giving the motivation for the personnel working well.

Emotional intelligence emphasizes understanding of oneself and others. Cooper and Sawaf (1997: 12) recognize that people with higher emotional intelligence can make a difference elaborate management scope as follows: (a) decision-making; (B) leadership; (C) opening good communication (honest); (D) the relationship of trust and teamwork; (E) customer loyalty; (F) creativity and innovation.

Emotional intelligence can be maintained and is a valuable skill to master in effective school management (Gutsteins, 2004: 29-30).

Emotional intelligence is produced from a combination of four integral components (Cherniss and Goleman, 2001: 27). according Goleman (2003: 39) are four important components in emotional intelligence is an essential tool in the effective management, these components are (a) selfawareness; (B) self-management; (C) social consciousness; (D) management relations.

The first component of emotional intelligence is selfawareness. It brings an awareness of emotions and the ability to express orally in a suitable manner (Goleman, 1999: 56). Self-awareness is the basis of emotional intelligence which can build on top of other components such as management, social awareness, and relationship management (Goleman, 1996: 47).

According to Salovey (in Goleman, 2001: 58) emotional intelligence has five main areas or major components, among others: recognizing emotions, managing emotions, motivating oneself, recognizing emotions in others, and build relationships.

Recognizing emotions means that a school principal selfaware, recognize feelings, when they're there/understand themselves and sure of her feelings in making decisions, and the inability to examine your feelings will make a school principal are in power feeling out of control, for example, put emotions (anger) on the subordinate to think about the impact of anger, for example, occur small groups, and it can happen that a split would result in the breakdown of an educational institution.

Managing emotions means that a school principal to handle feelings to make sense of that there can be revealed with a fitting and it depends on the awareness of teachers. How to manage your emotions at a school principal is to entertain yourself, let go of anxiety, moodiness and eliminate the offense will result in the emergence of emotions and influence the actions that can not be controlled or a bad decision.

Motivate yourself means a school principal to organize the best possible way to achieve the goals of the organization / institution he leads. How to master ourselves and motivate ourselves for recreation with principles that can be emulated by subordinates for example with the discipline of school hours and Principal have the spirit and the purpose for the education of children of the nation.

The ability of different principals in the area of emotional intelligence, because it is a natural thing for humans, who have a different nature setap people. There is a school principal who can deal with anxiety in itself, but there is also the principal that is difficult to calm the emotions / anger teacher, so head resulting in school perform actions that could hurt the feelings of teachers (subordinate). For example, there are teachers who are at odds with the other teachers, the school principal arbitrarily immediately give a warning (penalty) on the teacher without first investigating the problem and sensitize both the teacher. Principal action will cause fear to the head teacher. Meaning it cannot dampen the emotions/anger the teacher and when emotional intelligence capabilities on a self-principals, the habit of self-conscious and erepon the right to be able to fix these shortcomings.

In addition to the four essential components mentioned above, Goleman (2001: 274) there are seven other essential elements relating to an emotional intelligence are: confidence, curiosity, interest values, and skills, communicate and cooperate.

Confidence is a feeling that there is on the principal to control and master the behavior and actions in conveying knowledge and shaping the character of an institution. According Lightart (in Purwanto, 2015: 144) says that all education should be based on the belief that the child has a conscience.

Curiosity a feelings on the individual or principals who have the feeling of wanting to investigate everything that is positive and beneficial to himself or others or be good for subordinates in school. On the other hand in order not to close the more developing world developments.

Value is a desire and ability (inner) individual or principal to adjust and control the action with the corresponding pattern or educational purposes, duties as principal and sense of responsibility to subordinates and institutions are the main thing.

Entanglement is the ability of a person or the principal to engage with the noble responsibility in society and state based on feelings as citizens of Indonesia who are obliged to build the Indonesian state to build an educational institution. That is because for the nation's future are educated through educational institutions.

Information skills is the ability of a person or the principal have the verbal skills (language and literacy) and nonverbal (feeling or emotion) in managing and leading institutions and give character to the institution. This is done by way of, among others; exchange ideas, provide ideas and concepts to the students and other teachers to improve education in Indonesia.

Cooperative learning is one's ability principals to balance own needs (private) and the need for responsibility in the community (careers) in the lead agencies must work together with other institutions to achieve the goals of the education 
agency that maximum or establish institutions that are able to compete with the development community to face, life issues are increasingly challenging.

The school principal is self-conscious of his duty as a "model" or an example for his subordinates and the need to adapt (self-awareness) between the school environment (subordinate) to the mood of the principal. According to Mayer (in Goleman, 2001: 65) self-awareness means either alert to the mood and one's mind about the state / mood, the style of the (principal) in handling and overcoming emotions, among others; self-conscious grumpy or irritable, and easily discouraged.

Self-awareness is the ability of a person or principals tend to think positive their subordinates, when the mood is bad principals do not worry, insoluble problems and was able to break away from the mood when experienced alone, that is to say when teachers see the problems faced by subordinates the principal view of glasses "if I were him" even easier to control emotions (not easily upset).

Grumpy or irritable is the ability of principals feel the emotional irritability means an ability and not sensitive to his feelings, cannot even feel the feelings their subordinates. The Principals angry often lose control means irritable and cannot control their emotions, manifested by subordinate offensive remarks or actions that could lead to a sense of fear subordinate to the leader.

Abandonment is the ability of a person or a principal who easily surrender or give up sensitive to what is perceived, but tend to take for granted the mood so there is no attempt to change it, for example, teachers are faced classified as less disciplined headmaster accept it without any effort to want to change it, Usually the head at school who suffered from depression and sinking into despair or problems often faced.

If principals adjust to the mood of subordinates (teacher) or environment easily bring teachers that are in effect, then on the emotional level of their association will go more smoothly and this has become a regular activity of a school principal that social activities in the school environment. This method is usually owned by a democratic leader who havee charisma and has a high social intelligence. According to Hatch and Gardner (in Goleman, 2001: 166) the fundamentals of social intelligence, among others; organizing group, negotiated solution, social analysis.

Organizing group means that one or principals have the skills to be somebody democratic leader in the school, with regard to the principals could initiate or as an example for teachers and coordinate / make a demand that must be done is regulation school teacher and the teacher's task as educators. Negotiated solution means that one or principals have the skills to prevent conflict or finish conflicts that exist in the sense proficient in the field of diplomacy, for example, solve problems and prevent teacher who fell out with the other teachers.

Social analysis means that one or principals have the skills to understand the feelings their subordinates (teacher), detect or read the feelings of the students, and have concern and compassion high on the teacher.
The influence of emotional intelligence is caracter which include; (1) self-discipline, self-control, self-motivation, and guiding himself in completing a task / job; (2) morality of the critically important to build relationships between teachers and students and translate into a value of civilization and good behavior; (3) the art of democracy includes rule out impulse or the satisfaction of their own hearts, accepting viewpoint or opinion teacher as teacher, empathize or care about the teachers as well as altruism and compassion for high (Goleman, 2001: 407).

If the social intelligence skills coupled with emotional intelligence will create principals-principals are professionals in their field and have close social relations include communication, expertise and public confidence. Besides the skills to coordinate all the teams in the schools in the success of learning and educational purposes, to make a deal, continues to see things from the viewpoint of others or understand other people's feelings, promote cooperation and avoid conflict. On the other hand important owned by a school principal is willing to take the initiative, willing to motivate yourself to take responsibility and be able to organize themselves well in a clever means to divide their time and personal commitment to the profession or employment.

The foregoing is supported by Goleman (2001: 398) states that intelligence skills an emotional help and train principals in expanding views on school assignments, making the principal firm as the leader of the institution to shape the character of the institution he leads in accordance with the purpose

On the other hand Goleman (2001: 232) says that emotional intelligence is important in all areas of life. Therefore, in any education level, principals are required for good personality, patiently and made an example like other personnel. seen from the school and outside the scope of a school principal can be a leader who dared to take the initiative, willing to motivate yourself to take responsibility and self-regulation is good, it means smart in dividing time and commitment as principal. On the other hand at the elementary school level, principals could not bring the world to the head teacher of the school, but the principal who enters the world of teachers.

\subsection{Spiritual Intelligence}

Zohar and Marshall include aspects of the context of value as a part of the process of thinking / intelligence in meaningful life, for this they use the term spiritual intelligence (Spiritual Quotient / SQ) (Zohar and Marshall, 2000). Indications of spiritual intelligence in their view includes the ability to appreciate values and meanings, have self-awareness, flexible and adaptive, tend to look at things holistically, as well as the tendency to seek answers fundamental to situations of his life, and others.

For Zohar spirituality should not be attributed to the proximity of a person with this aspect of the divine, because according to a humanist or atheist can have a high spirituality. Agustian (2001a) gives meaning opposed to the value Danah 
Zohar, which states SQ associated with divinity or religious issues. Human intelligence to materialize because of the encouragement of conscience (nature), which comes from God with the elements of the nature of God or God-Spot, make man has a toughness personal and social resilience in realizing human success.

Spiritual Quotient by secular thinking has not been able to provide a comprehensive meaning to humans. The ability to appreciate values and meanings, have self-awareness, flexible and adaptive is still limited to the ability of yourself that could someday disappear without trust and confidence transcendental power that provides energy for humans. The realization that human life is nothing set, can provide a large enough power that can influence the human being in any condition, both normal as well as the conditions under which humans are faced with the problems of life.

Agustian (2001a) describes the emotional intelligence to work horizontally, which is a role only to the relationship between humans and humans, while spiritual intelligence is intelligence in the form of a vertical relationship to the Creator. Merging these three things will produce humans plenary ready for life and produce the effect of the success of what he did (see Figure 1).

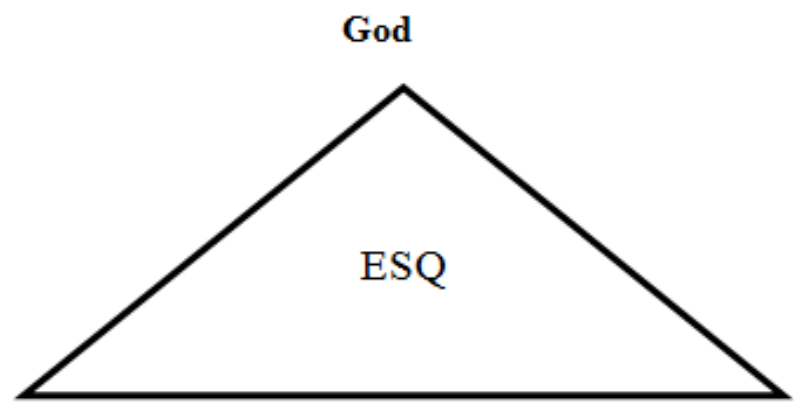

Human

Human|

Figure 1. Emotional intelligence to function horizontally.

According to Ali (2015) spiritual learning can not only learn theoretically be done with it. However, more important is to make the knowledge within themselves into consciousness. Based on this insight came not only from the spiritual person learns from books alone, but understanding gained will serve as a form of conscious behavior without coercion.

Spiritual intelligence is central intelligence brain function to integrate all human intelligence so completely intact intellectually, emotionally, and spiritually. According Khavari (in Nggermanto, 2014), spiritual intelligence is the faculty of the non-material dimensions or the human soul, which is a diamond that has not honed. The spiritual dimension is at the core of human or most personal areas of life and very important.

Spiritual intelligence according to Ginanjar (2006) is the ability to give spiritual meaning to the thought, behavior and activities as well as capable integrated IQ, EQ and SQ thoroughly. On the other hand, he argued that spiritual intelligence is a necessary basis for the proper functioning of the intellectual and emotional intelligence as effectively or even higher spiritual intelligence is intelligence that must be developed.

Similar disclosed by Mahayana (in Nggermanto, 2014) that the signs of people who have a high SQ, among others; has principles and a strong vision, able to see unity in diversity, able to put on each side of life, and is able to manage and survive the hardship and suffering.

Based on what was spoken by the Zohar (2005: 135-136), describes twelve hallmark of a human being has a high SQ, that is: (a) self-awareness; (b) Guided by its vision and mission; (c) Holism; (d) The spontaneity; (e) Concern; (f) Celebrate; (g) Independent on the environment; (h) trends; (i) The reability to guide; (j) take advantage of the misfortune positively; (k) Humility; (1) The taste of calling.

The same is expressed by Mahayana (in Nggermanto, 2014: 123) that the signs people have a high SQ, among others; has principles (principles of justice, truth, and goodness) and the vision of a strong, capable unity and diversity, able to interpret every side of life, and is able to manage and survive in adversity.

Based on some of the above description, an indicator that shows the spiritual intelligence, among others: (a) have a vision; (b) holistic thinking; (c) be able to explore and exploit the value; (d) establish affection; (e) humble; (f) forgiving; (g) is responsible; (h) to be believed: (i) gratitude and patience.

As for improving SQ among others, by increasing the use of tertiary psychological processes. The process is the tendency to ask why, to seek the interconnectedness of all things, remedy brought to the surface assumptions about where behind or in something, it becomes more meditative, little reach outside themselves, responsible, self-aware, more honest the self, and more brave.

The school principal described as people who have high expectations for staff and students. "The principal is that a lot of them know their duties and those who set the tone for their schools" (Lipham, 1985: 1).

The meaning of the word "leadership" is closely related to the meaning of the word "lead". Said lead implies the ability to mobilize all available resources in an organization so that it can be utilized optimally to achieve the goals set.

\subsection{Leadership}

School is an institution that is both complex and unique. Is complex because the school as an organization in which there are various dimensions to each other interrelated and mutually determine. Being is unique, because the school has its own character, where there is a learning process, the implementation of the civilizing of human life. Because of its complex and unique, the school as an organization requires a high degree of coordination. "The success is the success of the school principal." (Wahjosumijo, 1997: 349).

According Wahjosumidjo, in the practice of the organization, the word "lead" connotes moving, directing, guiding, protecting, fostering, set the example, encouragement, assistance, and so forth (Wahjosumijo, 1997: 
82). How many variables meaning contained in the word lead, giving an indication of how widespread the duties and roles of a leader of the organization. "Leadership" is usually defined by experts according to their personal views, as well as aspects of the phenomenon of interest is best for the expert concerned.

Yukl (1981: 2-5) define leadership as a virtue, personal behavior, influence on others, patterns of interaction, the cooperation relations between the role, the position of an administrative office, and the perception of others about the legitimacy of influence.

Meanwhile, Nawawi (2015: 81) define leadership as the ability to move, motivate, and influence the people that are willing to take action directed at achieving goals through the courage to take decisions about the activities to be carried out

From the definitions of leadership that these different, essentially of similarity assumption of a general nature such as: (1) in the phenomenon of group involves interaction between two or more persons, (2) in the process involves influencing, where the influence of deliberate (intentional influence) is used by leaders to subordinates.

In addition to the similarity of the common assumption, within the definition also has the distinction of a general nature as well as: (1) who use the influence, (2) the purpose of the effort to influence, and (3) how to influence it used Based on the description of the definition of leadership above, it appears that the key element of leadership is influence that person and, in turn due to the influence of it for those who want to be influenced.

Leadership is an important role in efforts to someone who plays the leading role in order to influence others in the organization / institution in order to achieve the goal. According Wirawan, "affect" is a process whereby people who influence trying to change the attitudes, behaviors, values, norms, beliefs, thoughts, and goals of people who are affected systematically (Wirawan, 2014: 135).

Based on the understanding of leadership, there are three interrelated elements, namely the human element, means, and purpose. To be able to treat these three elements in balance, a leader must have the knowledge, expertise and skills required in carrying out its leadership. Knowledge and these skills can be obtained from the experience learned from experience theory or in practice for becoming a leader. However unwittingly, a leader in the treatment of his leadership in his own way, and ways to use it is a reflection of the basic traits of leadership.

Owens said that "leadership is an interaction between parties which is led by the party led". Furthermore Kreither and Kinicki say that "leadership is an attempt to influence the members to achieve the goals of the organization voluntarily." In terms of matching Gibson (1938: 457) says "leadership is an attempt to use various types of influence rather than coercion to motivate members of the organization in order to achieve certain goals ". The third of the above equation are the core of the notion that there are two parties, one of which has the authority to regulate the others. Nevertheless In Nawawi (2015: 18-24) disclosed some sense of leadership that is different from the previous three experts by. Stoner (2014) quotes the opinion Churchill said that "leadership is the ability and directing skills, is a factor (activity) are essential to the effectiveness of the manager / leader". In this explanation, a leader self-ability to steer the organization to achieve goals.

According to Terry (in Winardi, 2015: 59-60) factors related to leadership are: (1) A leader affect the other party or parties led by its qualities such as: confidence, communicative ability, and awareness of its effects on the other hand, and with his perception of the situation at hand and subordinates; (2) The role of the leader and the degree of acceptance of it by the group concerned affect leadership; (3) The level to which tasks are explained, have an important effect; (4) the leader in question has the ability to determine what actions are best to achieve the objectives of the group; (5) The leadership style and the situation and the prevailing conditions affecting the results to be achieved.

Recognizing emotions in others it means the principal related to the self-awareness of emotional and social skills (social) that can generate empathy. Teachers who have high empathy will quickly grasp what is needed or desired, and perceived by their subordinates. According to Goleman (2001: 136) empathy is the ability to know how another person feels, and compassion that had a role in life.

Relationships means that principals can maintain relationships with teachers, staff, and community, it is easy to socialize (hang out with oraang others) and all areas of emotional intelligence mastered, will bolster the popularity of the principal good, and formed a democratic leadership in the lead and manage institutions properly.

Leadership in English commonly called leadership. Some definitions of leadership put forward by Terry (1972: 458) "Leadership is the relationship in which one person, or the leader, influences others to work together willingly on related tasks to attain that which the leader desires". Gibson (1988: 334) leadership is an effort to use the kind of influence rather than coercion (concessive) to motivate people achieves certain goals.

Davis (1985), leadership is the process of encouraging and helping others to work with enthusiasm achieve goals. Blanchard (1977) "Leadership is the process of influencing the activities of an individual or a group in efforts toward goal achievement in a given situation".

Based on these definitions, it will happen if the leadership in certain situations a person influence the behavior of others either individuals or groups. According to Blanchard's leadership as the process can be formulated as follows:

$$
\begin{gathered}
\mathrm{L}=\mathrm{f}_{1}(1, \mathrm{f} 2, \mathrm{~s}) \\
L=\text { Leadership, } f=\text { function, } l=\text { leader }, f_{2}=\text { follower, } s= \\
\text { situation }
\end{gathered}
$$

Formula 1. Leadership formula.

So from the formula of leadership is a function of the interaction between leaders, subordinates and the situation

So we can conclude is the school leadership is a way or 
business principals to influence, encourage, guide, direct, and moving teachers, staff, students, parents, and other relevant parties to work, participate in order to achieve the objectives has been established.

Wahyosumijo (1997: 25-26) suggests there are four different models of leadership when associated with personality traits of a leader. Namely: Model Fiedler (1974), Model houses Path Goal (1974), Model Vroom-Yetton (1973) and a model situation (1977). Of the four models that need to be developed is a model of leadership situation.

According to contingency theory of Fiedler in Sujak (1990: 17) successful leadership depend on the implementation of a leadership style to the demands of the situation. Applications style of leadership, in the process of adaptation to the situation could be through a process: (1) understand the style of leadership, (2) diagnose the situation, and (3) apply a leadership style that is relevant to the demands of the situation.

According to the House, where leaders give greater impetus to the fulfillment of these expectations, the greater the achievement to be acquired employees. House suggests four leadership styles that become a leader's behavior, namely: (1) achievement-oriented leadership, (2) leadership directive, (3) participative leadership, (4) supportive leadership.

Managerial implication against these forces are: (1). Supportive style effectively applied when subordinates are conducting routine tasks and tasks that are simple, effective also used when employees face a difficult task to do, by giving encouragement and cultivation of self-confidence. (2). Style directive, effectively applied when subordinates face a task that is not routine and are complex. By implementing this style, the leader can reduce ambivalence towards the tasks facing employees. Through the command form of manual labor, will help employees achieve the goals it claims to be the completion of tasks available to him. 3). Participative style, effectively used when a leader takes the necessary information in the decision making process, or when subordinates face tasks that are not routine and complex entity. 4). Achievement-oriented style, effectively used when subordinates just accept employment package, and subordinates are receptive to the decisions come from the top down, and were not included in the determination of activity. With the theory put forward by the House is that between leaders and subordinates demanded effective communication, in the form of encouragement from leaders to its employees in meeting the tasks that will be done subordinate to the expectations that existed at the leader.

\section{Research Method}

There are two independent variables in this study, namely emotional intelligence and wit spiritual. While the dependent variable is the effectiveness of school leadership.

The design of this research is described as follows:

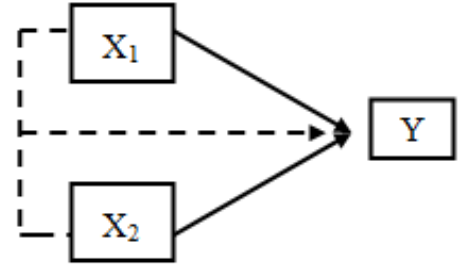

Figure 2. Research design.

The population in this study was all heads of secondary schools in the city of Surabaya with a total of 22 scattered around Surabaya. The sampling technique used is the census. That is because the number of population of less than 100 , then take all

Data collection techniques used in this research is to test and questionnaire shaped instrument (questionnaire). The test is used to find the level of emotional intelligence and the intelligence level spiritual. The questionnaire used to search the data effectiveness of school leadership.

Questionnaires about the effectiveness of school leadership-oriented and task-oriented human relationships are arranged in the form of multiple choice, the question is followed by four alternative answers are compiled sometimes ranging from positive to negative and sometimes from negative to positive. Scoring for each item of the highest 4 to 3 high enough, the answer is as low as 2 , and the answers are very low one.

The questionnaire used is about the effectiveness of school leadership above. In addition to the questionnaire also used the test EQ and SQ. Before it is used to test the validity and reliability, so that the instrument to be used really valid and can be used as a measuring tool.

Test the validity of research instruments is done by analyzing the relationship between scores of each of the questions with a total score of grains. To test the validity of the instruments, analytical techniques with Pearson Product Moment Correlation method with formula

$$
r_{x y}=\frac{n \sum X Y-\left(\sum X\right)\left(\sum Y\right)}{\sqrt{\left\{\left(n \cdot \sum X^{2}-\left(\sum X\right)^{2}\right)\right\}\left\{\left(n \cdot \sum Y^{2}-\left(\sum Y\right)^{2}\right)\right\}}}
$$

Formula 2. Product moment correlation.

To calculate a correlation coefficient of each items by using SPSS version 11.5. The decision rule is if $r_{x y}>r$ table then it means valid items and vice versa if $r_{x y}<r$ table the items were meant to be invalid, then the items in the instrument is invalid and cannot be used as a measuring tool. Therefore it needs to be improved, both the structure of the word (text) and content.

Reliability of the instrument was analyzed using Cronbach Alpha formula method. This method is used to look for internal reliability is to analyze the reliability of measuring instruments from one measurement. The formula is as follows: 


$$
r_{11}=\frac{k}{k-1}\left(1-\frac{S_{i}}{S_{t}}\right)
$$

Formula 3. Reliability.

The acceptance criteria was of reliability of each variable if the correlation coefficient Alpha $>0.60$ then all the data analyzed otherwise reliable or otherwise. If Alpha $<0.60$ then all the data being analyzed is declared unreliable.

In this research, there are three variables that were examined is the level of emotional intelligence $\left(\mathrm{X}_{1}\right)$, the level of intelligence spiritual $\left(\mathrm{X}_{2}\right)$, and the effectiveness of school leadership as the first independent variable $(\mathrm{Y})$.

Inferential statistical analysis used in this study is a simple linear regression and multiple linear regressions (multiple regressions).

Simple linear regression is used to determine the correlation of each independent variable and the dependent variable (referring to the formulation of the problem number 1 and 2).

While multiple linear regression is used to determine the correlation between the independent variables together with the dependent variable (referring to the formulation of the problem number 3 ).

The simple linear regression equation is:

$$
\hat{\mathrm{Y}}=\mathrm{a}_{\mathrm{o}}+\mathrm{bX}
$$

While multiple linear regression equation with two independent variables are:

$$
\begin{gathered}
\mathrm{Y}=\mathrm{a}_{\mathrm{o}}+\mathrm{b}_{1} \mathrm{X}_{1}+\mathrm{b}_{2} \mathrm{X}_{2} \\
\text { Formula 4. Linier Regretion. }
\end{gathered}
$$

Hypothesis testing is done by using a significance level of 0.05 . If the significance $F$ (probability) $<0.05$ then the null hypothesis (Ho) is rejected, and vice versa if $\mathrm{F}>0.05$ then the null hypothesis (Ho) is accepted. Meanwhile, to test multiple correlation coefficient significant or not used formula F. Test the entire process assisted with the research data processing using SPSS version 11.5.

\section{Findings and Discussion}

\subsection{Effect of Emotional Intelligence (X1) to the Principal Leadership Effectiveness (Y)}

Based on the results of a calculation of correlation coefficient analysis between variables emotional intelligence on the effectiveness of the leadership of the head of school, obtained the correlation coefficient between X1 and Y (ry1) amounted to 0,848 with significance level $(\mathrm{P})=0.000$. The significant level means less than 5\%, which means significant. Furthermore, based on the results of a calculation coefficient of determination obtained value contribution of $85.3 \%$.

So the working hypothesis (H1) is accepted and the null hypothesis (H0) was rejected so that there is a significant relationship between emotional intelligence to the effectiveness principal leadership.

Such findings prove the influence of emotional intelligence on the effectiveness of school leadership according to Goleman (2004: 23) states that under the leadership of emotionally intelligent, people (subordinates) to feel a level of comfort that is mutually beneficial. Therefore, it can mean that they can share ideas and learn from each other so that the organization runs compatible with the expected. Emotionally intelligent leaders would not only empathize with the emotions, but also express to groups. Social awareness especially empathetic support the next steps of the leader's job, which is to encourage and recognize the resonance by aligning themselves with the feelings of others when needed. However, in the same way a leader who lacks empathy will inadvertently voicing discordant notes, and speak and act in a way cause a negative reaction. Therefore, negative reactions caused by lack of empathy can cause an uncomfortable working environment, so that the institution becomes less than the maximum movement. Here, too, it is known that emotional intelligence is not emerging from a clear intellect but of the work of the human heart. Emotional intelligence that motivates a person to seek the benefits and potential, and to enable the aspirations and values most in, and turn from what is thought to be what is undertaken.

Hasri (2004: 20) describes the effective principals, which include the following: have a vision and make it happen with the teachers and staff. He has high expectations on performance, always observe the quality of teachers and the quality of students and encourage the use of time. Besides, an effective principal who always monitor individual performance of teachers, staff, students and schools. From all the indicators proposed by Hasri can be seen that there is an interaction between the principal and teachers.

Therefore a principal who has a high emotional intelligence can be assured it is always easier to interact with the teacher. Thus the principal can monitor each teacher's performance.

\subsection{Effect of Spiritual Intelligence (X2) of the Principal Leadership Effectiveness (Y)}

Based on the results of a calculation of correlation coefficient analysis between variables spiritual intelligence about the effectiveness of school leadership, the value of the correlation coefficient between $\mathrm{X} 2$ and $\mathrm{Y}$ (ry2) amounted to 1,014 with significance level $(P)=0.000$. The significant level means less than $5 \%$, which means significant. Furthermore, based on the results of a calculation coefficient of determination obtained values contributed $82 \%$.

So the working hypothesis (H1) is accepted and the null hypothesis (H0) was rejected so that there is a significant relationship between spiritual intelligence on the effectiveness of school leadership.

These findings prove the principal who has a high level of spiritual intelligence that will affect the effectiveness of leadership. 


\subsection{Effect of Emotional Intelligence (X1) and Spiritual Intelligence (X2) Against the Effectiveness Principal Leadership (Y)}

Based on the calculation analysis of multiple linear regression between $\mathrm{X} 1, \mathrm{X} 2$, and $\mathrm{Y}$ is known that the regression coefficient $\mathrm{F}$ count equal to 119.758 with a significant level $(\mathrm{P})=0.000$ means a significant result between emotional intelligence and spiritual intelligence on the effectiveness of the leadership of the head of public SMA in Surabaya,

While the correlation coefficient along generated at 0.963 showed a good correlation. On the other hand the coefficient of determination ( $\mathrm{R}$ Square) is 0.927 means that two variables explain predictor of emotional intelligence and spiritual intelligence had a correlation of $92.7 \%$ on the effectiveness of principals.

These findings suggest jointly between emotional intelligence and spiritual intelligence has significant influence with the effectiveness of school leadership.

These findings are also in accordance with the opinion of Robins (1996: 78) that the performance of a good teacher shows the results of effective leadership, and a clear mutual understanding between employers and workers about the rules and the application of fair punishment for deviant.

The implications of these findings indicate that good school leadership is a leadership that is able to combine human relations-oriented leadership and task-oriented. In addition to the principal is able to provide support, recognition, motivation, teamwork, and communication but also capable of providing clear tasks and responsibilities, and always monitor the teachers in carrying out the tasks given that they have high performance. Which in turn will be able to provide the knowledge, skills, and attitudes are good also in the students.

With the leadership behaviors that combine task orientation and human relations, then the staff in this case teachers feel cared for both in terms of tasks and obligations as well as rights and well-being, so that the programmed educational goals can be achieved effectively and efficiently.

\section{Conclusion}

Based on the formulation of the problem and research objectives proposed in this study, after a thorough analysis of the data obtained from the respondents can be drawn some conclusions as follows (1). There is a significant relationship between emotional intelligence on the effectiveness of the leadership of the head of state high school in the city of Surabaya with a correlation coefficient of 0.848 and effective contribution of $85.3 \%$. (2). There is a significant relationship between spiritual intelligence on the effectiveness of the leadership of the head of state high school in the city of Surabaya, the correlation coefficient of 1.014 and effective contribution of $82 \%$. (3). There is a significant relationship between emotional intelligence and spiritual intelligence together on the effectiveness of public SMA leadership chief in the city of Surabaya with correlation coefficients together at 0.963 and effective contribution of $92.7 \%$.

\section{References}

[1] Ali, H. M. (2015). Guru dalam Proses Belajar Mengajar jilid 2. Bandung: Sinar Baru Algesindo.

[2] Burhanuddin. (2015). Manajemen Pendidikan. Malang: Penerbit UM.

[3] Depdikbud. (1999). Panduan Manajemen Sekolah. Jakarta: Ditjen Dikdasmen-Ditdiknum.

[4] Ginanjar Agustian, Ary (2006). Rahasia Sukses Membangun Kecerdasan Emosi dan Spiritual ESQ. Arga: Jakarta.

[5] Ginanjar Agustian, Ary (2001). ESQ Berdasarkan 6 Rukun Iman dan 5 Rukun Islam. Jakarta: Arga.

[6] Goleman, Daniel, (2015) Kecerdasan Emotional: Mengapa EQ lebih penting dari pada IQ, Jakarta: Gramedia Pustaka Utama.

[7] Lipham, J. M. \& Hoeh, J. A. (1985). The Principalship: Concepts, Competencien, and Cases. New York: Longman. Inc.

[8] Nawawi, Hadari. (2015). Kepemimpinan Mengefektifkan Organisasi. Yogyakarta: Gadjah Mada University Press.

[9] Nggermanto, Agus (2014) Quantum Quetiont, Kecerdasan Kuantum, Bandung: Nuansa.

[10] Purwanto, M. N. (2015). Prinsip-prinsip dan Teknik Evaluasi Pengajaran. Bandung: Remaja Rosda Karya.

[11] Robins, S. P. (1996). Essentials of Organizational Behavior. New Jersey. USA: Prentice Hall International, Inc.

[12] Stoner, James A. F. and Freeman, Edward R. (2014). Manajemen. (Diterjemahkan oleh Wihelmus dan Benyamin). Jakarta: Intermedia.

[13] Undang-undang Republik Indonesia No. 20 tahun 2003 tentang Sistem Pendidikan Nasional.

[14] Wahjosumidjo. (1997) Kepemimpinan Kepala Sekolah, Tinjauan Teoritik dan Permasalahannya. Jakarta: PT Raja Grafindo Persada.

[15] William, Daniel. (1994). Leadership for the $21^{\text {st }}$ Century: Life Insurance Leadership Study. Boston: Hay Group.

[16] Winardi. (2015). Kepemimpinan Dalam Manajemen. Jakarta: PT Rineka Cipta.

[17] Wirawan. (2014). Kapita Selekta Teori Kepemimpinan: Pengantar untuk Praktek dan Penelitian. Jakarta: Yayasan Bangun Indonesia \& UHAMKA Press Prentice Hall International, Inc. 